\title{
$\mathrm{Au}-\mathrm{Co}$ 合金めっき膜の微細構造と熱平衡状態図の関係
}

\author{
井上晃一郎 1 ,*1 佐々木伸人 $1, * 2$ 笹平 崇 $^{2}$ 渡 邊 徹 ${ }^{3}$ 中田 毅 1
}

\author{
1 芝浦工業大学工学部材料工学科 \\ 2日本エレクトロプレイティングエンジニヤース株式会社 \\ 3 東京都立大学大学院工学研究科応用化学専攻
}

J. Japan Inst. Metals, Vol. 69, No. 1 (2005), pp. 147-151

(C) 2005 The Japan Institute of Metals

\section{The Relationship between Microstructure and the Thermal Equilibrium Diagram of Au-Co Alloy Electrodeposit}

\author{
Koichiro Inoue ${ }^{1, * 1}$, Nobuto Sasaki ${ }^{1, * 2}$, Takashi Sasahira ${ }^{2}$, Tohru Watanabe ${ }^{3}$ and Takeshi Nakata ${ }^{1}$ \\ ${ }^{1}$ Material Engineering Dept., Faculty of Engineering, Shibaura Institute of Technology, Tokyo 108-8548 \\ ${ }^{2}$ Electroplating Engineers of Japan, Co., Ltd., Hiratsuka 254-0076 \\ ${ }^{3}$ Applied Chemical Dept., Graduate School of Engineering, Tokyo Metropolitan University, Tokyo 192-0397
}

$\mathrm{An} \mathrm{Au}-\mathrm{Co}$ alloy with an extensive composition range was electrodeposited from a gold sulfite and cobalt sulfate mixture. The $\mathrm{Au}-\mathrm{Co}$ alloy electrodeposits were analyzed by XRD and TEM and the relationship between the phase and thermal equilibrium diagrams was investigated. The $\mathrm{Au}-\mathrm{Co}$ alloy electrodeposits formed a solid solution over an extensive composition range. It was also revealed that the composition of the electrodeposited $\mathrm{Au}-\mathrm{Co}$ alloy was equal to that of the quenched phase at a high temperature, about $950^{\circ} \mathrm{C}$.

(Received July 13, 2004; Accepted November 26, 2004)

Keywords: gold sulfite, cobalt sulfate, gold-cobalt alloy, electrodeposits, microstructure, phase, equilibrium diagram

\section{1. 緒言}

めっき膜のほとんどの物性はめっき膜の結晶学的構造に依 存する，そのため，めっき膜の物性を制御するためには，め っき膜の微細構造を明らかにする必要がある. めっきに関す る研究は, 浴中の化学反応や, 電極表面上の電気化学反応に 関するものが多く1-5), 膜の結晶学的構造に関する詳細な報 告は少ない. 著者の一人はこれまで種々の合金めっき膜の構 造と熱平衡状態図との関係について検討を行ってきたが，そ の結果，次のことが明らかとなっている．めっき法によって 形成される膜の組織は, 熱平衡のものもあるが, アモルファ スや準安定結晶, そして過飽和固溶体などの準安定相をしば しば形成させる，そして，これらの相はめっき条件(過電圧 やアニオン種, $\mathrm{pH}$ など)に依存せず, 形成された膜の組成 によってほぼ一義的に決まるものであることが分かってき た6,7). また，このような準安定な相を形成することから，

*1 芝浦工業大学大学院生, 現在 : エヌ・イー ケムキャット秼表 面処理薬品事業部 (Graduate Student, Shibanura Institute of Technology, Present address: N.E. CHEMCAT CORPORATION)

*2 芝浦工業大学大学院生, 現在 : 日本メクトロン珠材料開発部 (Graduate Student, Shibaura Institute of Technology, Present address: NIPPON MEKTRON Ltd.)
めっき膜は高温で安定な組織の急冷固体であると考えられる. 本研究はそのような研究の一つとして, Au-Co 合金めっ きを取り上げた． Au-Co 二元合金の平衡状態図は Fig. 1(A) に示すように典型的な共晶型の状態図である. そして, 常温 では $\mathrm{Au}$ 結晶に Co を, また Co 結晶には $\mathrm{Au}$ をほとんど固 溶しないが，共晶温度 $\left(996^{\circ} \mathrm{C}\right)$ では $\mathrm{Au}$ 結晶中に Co を 23.7

(A)

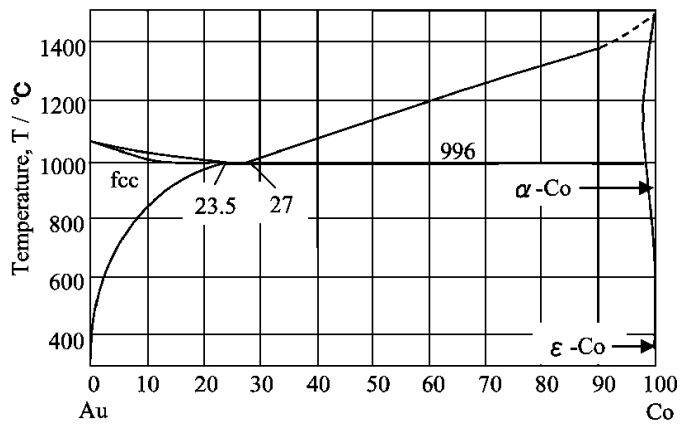

(B)

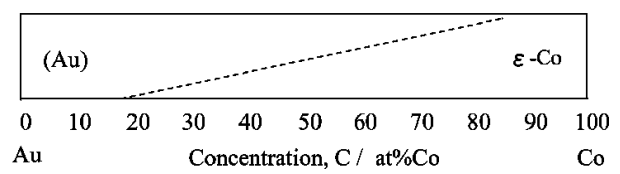

Fig. 1 Thermal equilibrium diagram of $\mathrm{Au}-\mathrm{Co}$ alloy (A), and phase diagram of deposited $\mathrm{Au}-\mathrm{Co}$ alloy film obtained in this investigation (B). 
at $\%$ ま゙固溶でき，Co 結晶中には Au を数\%固溶できるこ とを示している。

一般的に $\mathrm{Au}-\mathrm{Co}$ 合金めっき膜は，硬質金めっき膜と呼ば れ， $\mathrm{Au}-1.0$ mass $\% \mathrm{Co}$ の組成が良好な耐食性，耐摩耗性と 硬度を示すため，接点材料として広く用いられている8). そ のため，電析 $\mathrm{Au}-\mathrm{Co}$ 合金膜についてはこれまでにもいくつ かの報告がある ${ }^{9-11)}$ が，それらは $\mathrm{Au}-$ 数 $\operatorname{mass} \% \mathrm{Co}$ 程度まで のもので，実用的な組成範囲に限られている. そこで，本研 究では実用的な数 mass $\% \mathrm{Co}$ 程度の合金組成範囲を含め，ほ ぼ全組成領域の電析 $\mathrm{Au}-\mathrm{Co}$ 合金めっき膜を得，その微細構 造と熱平衡状態図との関係について検討を行った。

\section{2. 実 験 方 法}

本研究で用いた電析浴の組成と電析条件を Table 1 に示 す. 浴は亜硫酸 $\mathrm{Au}$ 浴と硫酸 Co 浴を混合したものである. それぞれの使用可能な $\mathrm{pH}$ の範囲は, 亜硫酸 $\mathrm{Au}$ 浴では $\mathrm{pH}$ $6.2 \sim 8.5$ で，硫酸 $\mathrm{Co}$ 浴では約 $\mathrm{pH} 1.0 \sim 5.0$ であり，異なっ ている. そのため, これら 2 種類の塩を混合すると, 沈殿 を生じ, 建浴できない。そこで, 硫酸 Co 浴にグルコン酸ナ トリウムを添加し, あらかじめ, 使用可能な $\mathrm{pH}$ の範囲を中 性側へと拡大したものに亜硫酸 $\mathrm{Au}$ 浴を混合した。電析浴の 全金属塩 $(\mathrm{Au}+\mathrm{Co})$ 濃度を $0.2 \mathrm{~mol} / \mathrm{L}$ とし, 浴の組成は, $\mathrm{Au}$ とCo をモル比でそれぞれ $1: 4,1: 9,1 ： 14$ と変化させ た。浴温は全ての条件で $50^{\circ} \mathrm{C}$ 一定とした。また，電流密度 は $10 \sim 1000 \mathrm{~A} \cdot \mathrm{m}^{-2}$ と変化させたが，めっき時間は電流密 度に関係なく，40C(クーロン)一定とした。アノードには $\mathrm{Ti}$ のメッシュに Pt をコーティングした Pt/Ti メッシュを用 い，擋拌はマグネティックスターラーにて一定速度で行っ た. めっき基板は, マスキングテープでめっき面積が $2 \mathrm{~cm}^{2}$ となるようにした多結晶銅板上に，無電解 $\mathrm{Ni}-\mathrm{P}$ アルファ ス合金めっきを施し，さらにその上に $\mathrm{Au}$ ストライクめっき したものを用いた．本実験でこのような基板を用いたのは次 の理由による．基板に結晶質の金属板を用いると，その上に 形成されるめっき膜は基板の結晶の影響(エピタキシャル)を 受け，その金属めっきの，またそのめっき条件ならではの構 造をとりにくい，そのため， $\mathrm{Cu}$ 板に無電解めっき法によっ てアモルファス $\mathrm{Ni}-\mathrm{P}$ 合金めっき膜を施して使用するように した.しかし，この基板を上述の $\mathrm{Au}-\mathrm{Co}$ 合金めっき浴に浸 漬すると, 基板の $\mathrm{Ni}$ が溶解し, $\mathrm{Au}$ が置換析出する. それ を防ぐために，アモルファス $\mathrm{Ni}-\mathrm{P}$ 合金めっき膜上にストラ イク $\mathrm{Au}$ めっき $100 \mathrm{~nm}$ 厚施し, 置換析出が起こらないよ

Table 1 Plating bath composition and plating conditions.

\begin{tabular}{ll}
\hline Plating bath & $\begin{array}{l}\mathrm{CoSO}_{4} \cdot 7 \mathrm{H}_{2} \mathrm{O} \\
\mathrm{Na}_{3} \mathrm{Au}\left(\mathrm{SO}_{3}\right)_{2} \\
\mathrm{Au}: \mathrm{Co}(\mathrm{mol})=1: 4,1: 9,1: 14\end{array}$ \\
\hline Bath temperature & $50^{\circ} \mathrm{C}$ \\
Current density & $10 \sim 1000 \mathrm{~A} \cdot \mathrm{Co}=0.2 \mathrm{~mol} / \mathrm{L}$ \\
Coulometric & $40 \mathrm{coulomb}$ \\
Substrate & $\mathrm{Ni}-\mathrm{P}$ amorphous plated film with Au strike plated film \\
Anode & Plated Pt on Ti mesh \\
Agitation & Magnetic stirring \\
\hline
\end{tabular}

うにした。このストライク $\mathrm{Au}$ めっき膜の結晶はアモルファ スに近いほど微細であるため，XRDではほとんど回折ピー クを示さず，また，配向していないことを確認している。

$\mathrm{Au}-\mathrm{Co}$ 合金めっきは電流密度一定の定電解法を用いた.

得られた合金電析膜の表面形態は SEM (日立製作所侏製 S-4500)により観察し, Au および Co の定量分析は SEM 付 属の EDX(堀場製作所侏製 EMAX5770)によって行った。 カソード分極測定は照合電極として $\mathrm{Ag} / \mathrm{AgCl}$ 電極を用い, ポテンショスタットを用いた。 得られた電析 $\mathrm{Au}-\mathrm{Co}$ 合金膜 の相構造は XRD および TEM (日本電子秼製 JEM-2010)に よって解析した。 TEM 観察用試料はミクロトーム (Raichert Nissei 社製，URTRACUT N)にて薄片加工し た. また，めっき膜の熱処理は真空電気炉中にて $300^{\circ} \mathrm{C}, 1$ 時間行った.

\section{3. 実験結果および考察}

\section{1 電析電流密度と膜中 $\mathrm{Co}$ 濃度}

Fig. 2 に電析電流密度と膜中 Co 濃度の関係を示す．この

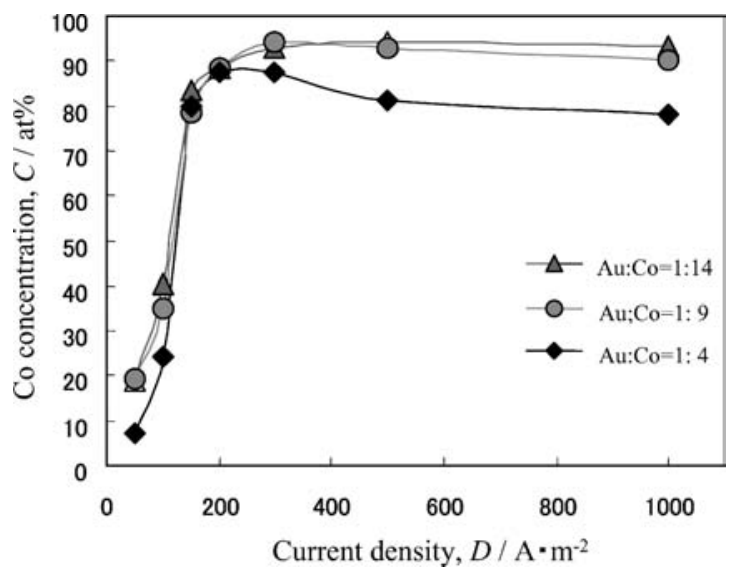

Fig. 2 Current density and Co concentration of deposits with varied bath composition.
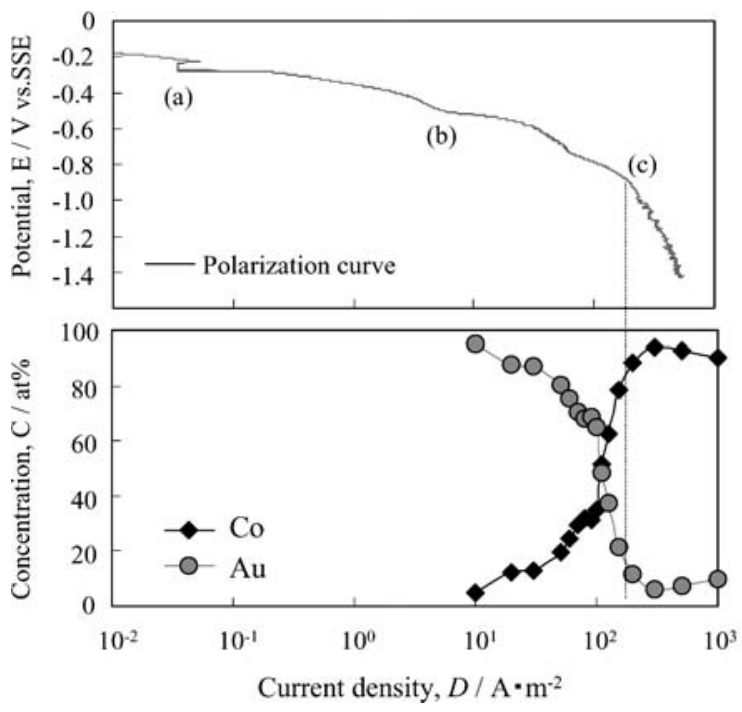

(B)

Fig. 3 Polarization curve obtained in a sulfite bath (A) (Au : $\mathrm{Co}=1: 9)$ and composition of Au-Co alloy deposits (B). 
図には浴組成を変化させた結果についても示した，いずれの 浴濃度でも, 電流密度の増加とともに膜中の Co 濃度が増加 している. 特に，5～ $20 \mathrm{~A} \cdot \mathrm{m}^{-2}$ の低電流密度域でいずれも Co 濃度の増加は著しく, また, それ以上の電流密度ではほ とんど変化せず，ほぼ一定の值となっている.

Fig. 3 に $\mathrm{Au}: \mathrm{Co}=1: 9$ の浴に打ける電流密度と電位 (A), および膜組成 $(\mathrm{B})$ の関係を示す。これより, 自然電位 よりわずかに卑な電位で現れる電流密度の急激な上昇 $(\mathrm{a})$ が $\mathrm{Au}$ の析出開始電位であり, 次に現れる(b)が Co の析出開始 電位であり，(c) は拡散限界電流密度である。この結果に基 づいて, 本研究では $\mathrm{Au}: \mathrm{Co}=1: 9$ の浴を用いて (b) 点から (c) 点の電流密度範囲で, $\mathrm{Au}-5.1$ at $\% \mathrm{Co} \sim 94.0$ at $\% \mathrm{Co}$ の組 成の合金めっき膜を得, それらの構造について検討した.

\section{$3.2 \mathrm{Au}-\mathrm{Co}$ 合金電析膜の $\mathrm{X}$ 線回折結果}

Fig. 4 に各組成の Au-Co 合金電析膜の X 線回折図形を示 す. $\mathrm{Au}-5.1$ at $\% \mathrm{Co} \sim \mathrm{Au}-51.3$ at $\% \mathrm{Co}$ の組成範囲のものは $\mathrm{Au}$ の (111)，(200),(220) 拈よび(311) 面からの回折ピーク のみが現れ，このピークは膜中の Co 量の増加に伴って高角 度側へとシフトし，さらにブロードになっている．膜中の Co 量とピークのシフトの関係を Fig. 5 に示す．このうち， (111) 面の回折角加ら, Au 結晶の格子定数を計算し, 膜組 成に対してプロットしたものが Fig. 6 である. 図中には $\mathrm{Au}$ の格子定数 $(0.4078 \mathrm{~nm})$ と fcc $の ~ \alpha-\operatorname{Co}$ の格子定数 $(0.3545$ $\mathrm{nm}$ ) とを直線で結んだV Vegard 則の直線(実線) も示した。 そ の結果, プロットはVegard 則の直線に乗る部分 (図中実線) と, Vegard 則の直線から外れた水平線 (図中一点鎖線)の二 つの直線に分けることができる. その分岐は約 18 at \% Co で ある.このことから，この合金めっき膜は約 18 at \% Co まで は $\mathrm{Au}$ 結晶中に Co を固溶した均一相であるといえる。 ま た，それ以上 Co を合金化しためっき膜は熱平衡状態図では， Co の結晶が現れるはずである。しかし，めっき膜の XRD の回折図形(Fig. 4)には現れておらず，ぞのようになってい るかは明らかではない。しかし，これまでの $\mathrm{Ag}-\mathrm{Co}$ 合金め っき12)や $\mathrm{Au}-\mathrm{Ni}$ 合金めっき13), $\mathrm{Au}-\mathrm{Fe}$ 合金めっき14)膜の組 織も同様に, 二元合金の内の高融点金属の方の回折図形はい

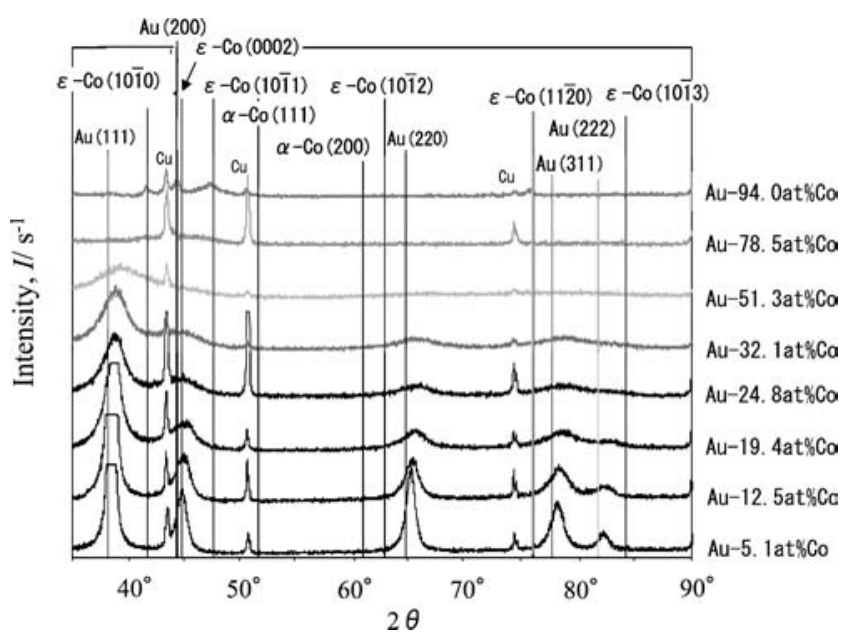

Fig. 4 XRD results of $\mathrm{Au}-\mathrm{Co}$ alloy deposits.
ずれもブロードで，結晶はアモルファスに近いほど微細化し ていた。本合金めっき膜の場合も Co 結晶はアモルファスに 近いほど微細になっているものと考える. 78.5 at\% Co の Co 高濃度側のめっき膜では, 前述した固溶体 $(\mathrm{Au}$ 中にCo を固 溶)の回折ピークも見られず，XRDの回折図形では $2 \theta$ が約 40 ５0にブロードな回折図形が見られるのみである.

\section{$3.3 \mathrm{Au}-\mathrm{Co}$ 合金電析膜の TEM 観察結果}

$\mathrm{Au}-78.5$ at\% $\mathrm{Co}$ の $\mathrm{Co}$ 高濃度側のめっき膜の構造はアモル ファスであるか微細な結晶の集合体であるかについて検討す るために，この $\mathrm{Au}-78.5$ at\% Co 合金めっき膜の断面を TEM で観察した. その結果を Fig. 7 に示す. 基板の圧延板 上の $\mathrm{Ni}-\mathrm{P}$ アルファス合金めっき膜と，その上に形成され た電析 $\mathrm{Au}-\mathrm{Co}$ 合金めっき膜が観察される. ストライク $\mathrm{Au}$ めっき膜は極めて薄いので観察することは出来ない. 暗視野 像では合金めっき膜は微細な結晶を示しており，また，電子 線回折図形では高指数の回折リングも現れている.このこと

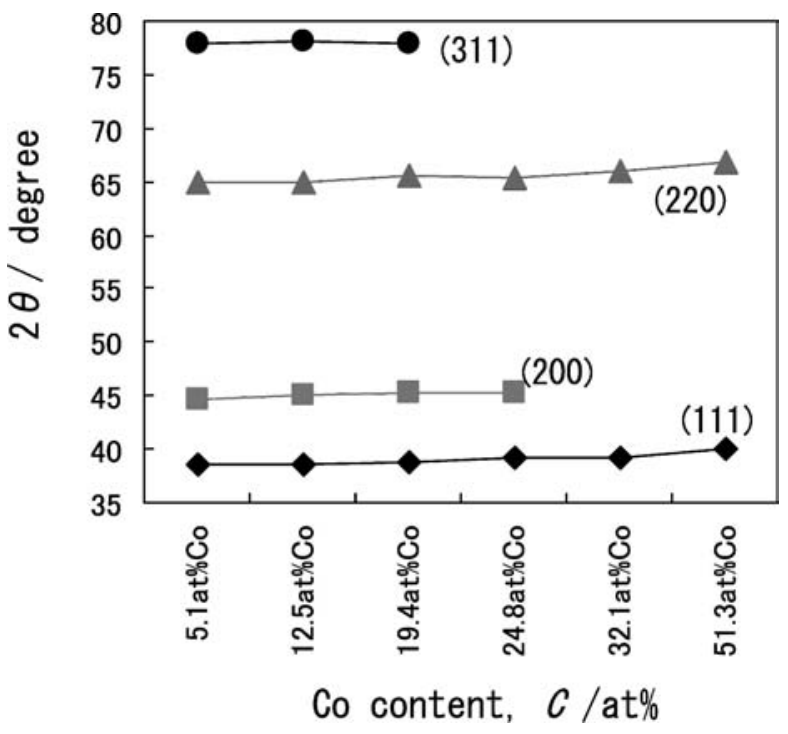

Fig. 5 XRD results with variation in Co content. The gold crystal diffraction peak shifts with increasing Co content.

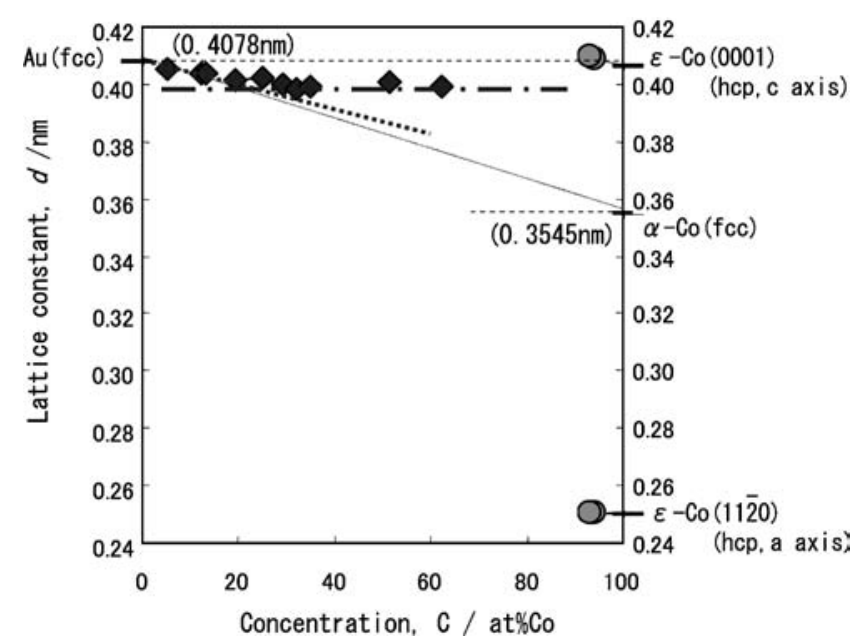

Fig. 6 Relationship between Co concentration and lattice constants of deposited $\mathrm{Au}-\mathrm{Co}$ alloy films. 
(a)

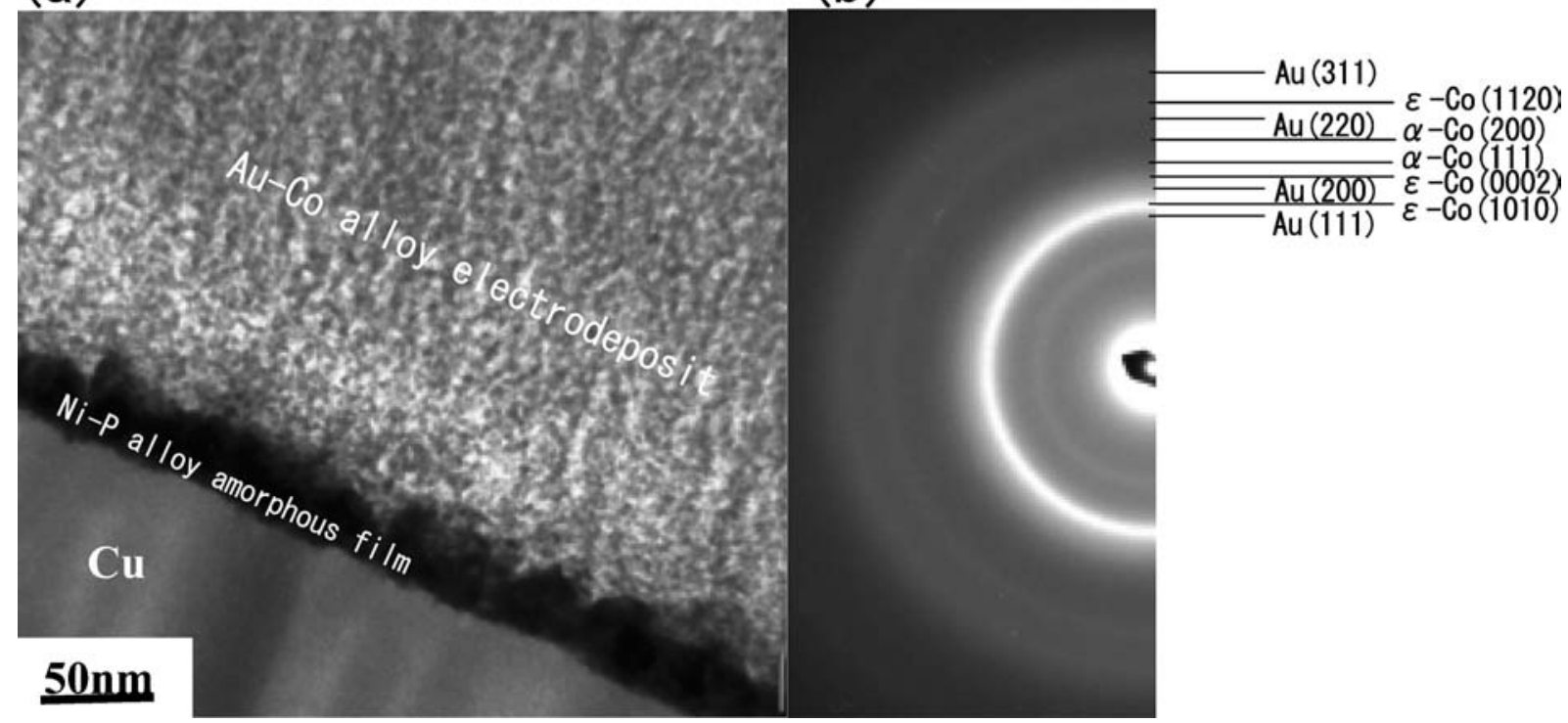

(b)

Fig. 7 TEM dark field image (a) and electron diffraction patterns (b) of $\mathrm{Au}-78.5$ at\% Co electrodeposit.
から，このめっき膜は極めて微細な結晶の集合体であると考 えられる.さらに 94.0 at \% Co では hcp 構造を持つ $\varepsilon^{-}$Co $の$ 回折ピークが現れている。 しかし，このときの $\varepsilon-$ Co の結晶 の $c$ 軸の格子定数 $(0.4089 \mathrm{~nm})$ は JCPDS で示された值の $0.4061 \mathrm{~nm}$ よりも大きく, $\mathrm{Au}$ の格子定数 $(0.4078 \mathrm{~nm})$ との 中間の值を示している，このことから，この $\varepsilon-$ Co の結晶は $\mathrm{Au}$ を固溶しているものと考えられる. また，この組成のめ っき膜は前述した $\mathrm{Au}$ の固溶体の回折ピークも, $\alpha-\operatorname{Co} の$ 回 折ピークも見られていない. 94.0 at \% Co 付近の組成のもの は, Co 結晶中に $\mathrm{Au}$ が過飽和に固溶した微細な結晶の集合 した組織であると考えられる。

以上の結果から，本実験の $\mathrm{Au}-\mathrm{Co}$ 合金めっき膜の相図を Fig. 1 の熱平衡状態図に照合させて（B)に示した。その結 果, 電析法で得られる $\mathrm{Au}-\mathrm{Co}$ 合金めっき膜の組織は, 約 18 at $\% \mathrm{Co}$ までは, Co を過飽和に固溶した $\mathrm{Au}$ の準安定相であ り, Co 高濃度側では, $\mathrm{Au}$ と過飽和に固溶した $\varepsilon^{-} \mathrm{Co}$ の集合 体から出来ていると考えられる. また，その間約 18 at $\% \mathrm{Co}$ 以上 94.0 at $\%$ Co 以下のものは Fig. 7 の TEM 像から判断し て $\mathrm{Au}$ 固溶体と $\varepsilon^{-} \mathrm{Co}$ とが共存した共晶型の組織を形成させ ていると考えられる。しかし，それらいずれの結晶も極めて 微細で，特に Au-78.5 at\%Co のものは回折ピークが極めて 弱く, この組成のめっき膜の結晶が最も微細であると考えら れる。

以上のように, 電析法によって形成された $\mathrm{Au}-\mathrm{Co}$ 合金め っき膜は熱安定な構造ではなく, Au も Co も準安定な過飽 和固溶体の共晶組織であることが分かった。 そこで,これら のめっき膜を $300^{\circ} \mathrm{C}$ で 1 時間熱し, XRD 測定した結果を Fig. 8 に示す. その結果，めっきのままで，高角度側にシフ トしていた Auの(111) 回折ピークはいずれも JCPDS に示 されている回折位置 $\left(2 \theta=38.2^{\circ}\right)$ に一致すると共に, よりシ ヤープとなり, 結晶粒を成長させていることが分かる．この ことから，Auの結晶中に過飽和に固溶していた Co の原子

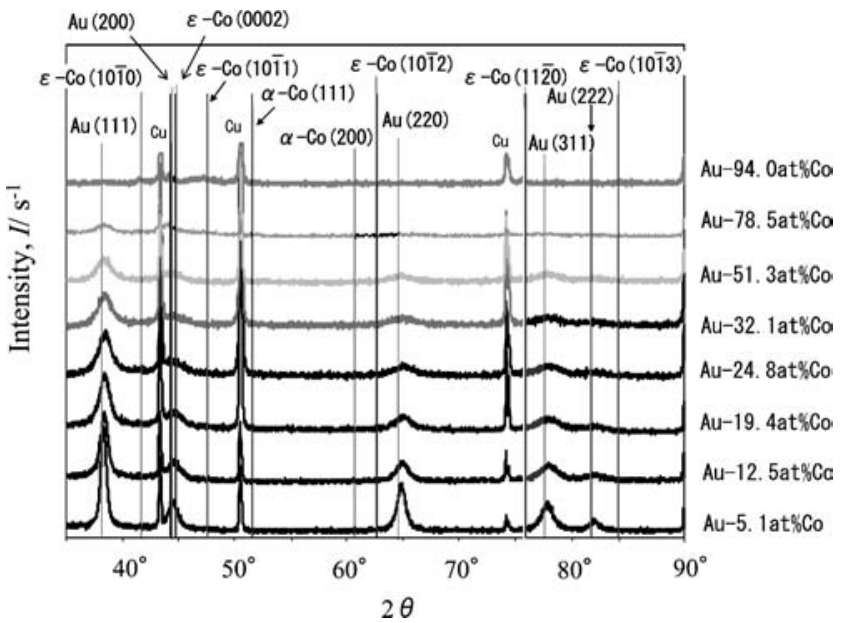

Fig. 8 XRD results of $\mathrm{Au}-\mathrm{Co}$ deposits annealed at $300^{\circ} \mathrm{C}$ for 1 hour.

は $\mathrm{Au}$ 結晶外に脱出し, $\mathrm{Au}$ は安定な結晶となり, より大き く成長したと考えられる。しかし，Co の高濃度側で見られ る Co 結晶は熱処理前とほとんど変化せず，熱的に比較的安 定であると考えられた.

\section{4. 結言}

本研究により, 電析法によって得られた $\mathrm{Au}-\mathrm{Co}$ 合金電析 膜の構造は次のようであることが分かった.

$\mathrm{Au}-\mathrm{Co}$ 合金電析膜の組織は約 18 at \% Co まで $\mathrm{Au}$ 中に Co を固溶して過飽和固溶体を形成し, 94.0 at \% 以上の Co 合金 めっき膜では $\varepsilon-\mathrm{Co}$ 中に $\mathrm{Au}$ を固溶した過飽和固溶体を形成 する，そして，それらの間の組成ではそれらの過飽和固溶体 の共晶組織である。 また，それらの結晶は約 78.5 at $\%$ Co の 時, 最も微細な結晶の集合体となる.すなわち, $\mathrm{Au}-\mathrm{Co}$ 電 析合金めっき膜は約 $950^{\circ} \mathrm{C}$ における相を急冷した組織であ 
ると考えられた.

文献

1) H. Gerisher: Electrochem. Acta 2(1960) 50.

2) J. O'M. Bockris and Razmney: Fundamental Aspects of Electrocrystallization, (Plenum Publ. Corp., 1967) pp. 155

3) J. O'M. Bockris: The Mechanism of Electrodeposition of Metals, Modern Aspects of Electrochemistry, No. 3 (1964) 224.

4) Rene Winand: Electrochem. Acta 39(1994) 1091.

5) S. Haruyama: Denkikagaku 31 (1963) 478.
6) T. Watanabe: Surf. Sci. Soc. Japan, 2nd Fundamental Seminar of Thin Film (1999) 151-131.

7) T. Watanabe: Materia Japan 40 (2001) 871-878.

8) K. Aotani: GOUKIN-MEKKI II, (NIPPON PLATING ASSOCIATION, 2001) 65.

9) N. P. Fedot'ev, N. M. Ostroumova and P. M. Vyacheslavov: Zhur. Priklad. Khim 29(1956) 489-492.

10) E. Raub and K. Bihmier: Gmumd 11(1937) 59-65.

11) B. D. Ostrow and F. I. Nobel: Prod. Am. Electroplater's Soc. (1960) pp. 68-73.

12) N. Igarashi and T. Watanabe: J. Surf. Fin. Soc. 51(2000) 414.

13) Y. Shimizu and Y. Tanabe: J. Surf. Fin. Soc. 27 (1976) 20

14) K. Inoue, T. Nakata, K. Shiokawa and T. Watanabe: Collected Abstract of the 2001 Autumm Meeting of the Japan Institute of Metal, pp. 417. 